\title{
Stolons Reserves and Spring Green-up of Seeded Bermudagrass Cultivars in a Transition Zone Environment
}

\author{
Maurizio Giolo \\ INRAN ENSE - Unit of Verona, via Ca' Nova Zampieri 37, 37057 S. G. \\ Lupatoto (VR), Italy
}

Stefano Macolino ${ }^{1}$

University of Padova, Department of Agronomy, Food, Natural Resources, Animals, and Environment, AGRIPOLIS, Viale dell'Universitá 16, Legnaro, Padova 35020, Italy

Erica Barolo

INRAN ENSE - Unit of Verona, via Ca' Nova Zampieri 37, 37057 S. G. Lupatoto (VR), Italy; and University of Padova, Department of Agronomy, Food, Natural Resources, Animals, and Environment, AGRIPOLIS, Viale dell'Universitá 16, Legnaro, Padova 35020, Italy

\section{Filippo Rimi}

University of Padova, Department of Agronomy, Food, Natural Resources, Animals, and Environment, AGRIPOLIS, Viale dell'Universitá 16, Legnaro, Padova 35020, Italy

Additional index words. Cynodon dactylon, starch, water-soluble carbohydrates, crude protein, winter dormancy

\begin{abstract}
Bermudagrass is the most widely used warm-season turf species in the transition zones of Europe. The Venetian valley (northeastern Italy) is a typical transitional zone, characterized by cold winters and hot summers, where the performance of bermudagrass mostly depends on cold tolerance and duration of winter dormancy. A 2-year field study was conducted from May 2009 to July 2011 at the agricultural experimental farm of Padova University. The objective of this study was to assess the relationships occurring between spring green-up of seeded bermudagrasses and their nonstructural carbohydrates and crude protein (CP) content in stolons during late winter. The cultivars used were 'Caribe', 'Mohawk', 'Princess-77', 'Sultan', 'SWI 1012', and 'Jackpot'. The plots were seeded in May 2009 and turf samples were collected in Mar. 2010 and 2011 for determination of stolons dry weight, diameter, and content of carbohydrates and CP. 'Princess-77' had lower content of starch in stolons compared with the other cultivars and was characterized by late spring green-up. The cultivars tested showed wide differences in stolons morphology (dry weight and diameter), whereas there were poor diversity for $\mathrm{CP}$ and water-soluble carbohydrates (WSC) in both years of research. Correlation analyses indicated a negative relationship between the days of the year necessary for spring green-up and stolons starch content and also between $\mathrm{CP}$ and starch. Moreover, there was a positive correlation between stolons starch and diameter, suggesting that spring green-up may be enhanced by selection of high starch-accumulating cultivars having coarse stolons.
\end{abstract}

Turfgrass water conservation has become a necessity in many parts of the world and several strategies are currently promoted to limit the use of potable water for irrigation. Water conservation strategies include widespread use of drought-tolerant warm-season grasses such as bermudagrass (Cynodon spp.) and zoysiagrass (Zoysia spp.) instead of the less efficient cool-season grasses. Bermudagrass is

Received for publication 4 Feb. 2013. Accepted for publication 25 Mar. 2013.

${ }^{1}$ To whom reprint requests should be addressed; e-mail stefano.macolino@unipd.it. the spring (Anderson et al., 2007; Patton et al., 2008).

Bermudagrass development is influenced by the length of photoperiod and its growth is reduced or inhibited during months of short photoperiod (Sinclair et al., 2001). However, it has been widely demonstrated that some cultivars are more responsive than others to photoperiod (Burton et al., 1988; Trenholm et al., 1998). Nonetheless, the main factor limiting the area of adaptation of bermudagrass is temperature. In general, when average daytime temperatures drop below $10^{\circ} \mathrm{C}$, bermudagrass enters dormancy, and when they drop below $-12{ }^{\circ} \mathrm{C}$, it may be subject to winterkill (Duble, 1996). The low-temperature tolerance depends on a combination of several causes, including environmental conditions, cultural practices, and especially genetic factors (Anderson and Taliaferro, 2002; Beard, 1973; Blum, 1988; Harlvonson and Guertin, 2003). Anderson et al. $(2003,2007)$ reported high correspondence between laboratory evaluations of freeze tolerance and field observations, although they noted that extreme field conditions may induce a higher level of acclimation compared with acclimation chambers. The plant's ability to withstand lethal, cold temperatures is a complex phenomenon and includes mechanisms of freezing tolerance and avoidance, which are commonly enhanced by a gradual decrease of temperatures (acclimation) (Hannah et al., 2006; Zhen and Ungerer, 2008).

Bermudagrass survives the dormancy period using reserves accumulated during the previous growing season in storage organs such as stolons and rhizomes. The main reserves of turfgrasses include nonstructural carbohydrates and nitrogen compounds (Graber et al., 1927; Macolino et al., 2010). Nonstructural carbohydrates (starch and WSC) are used for maintaining respiration when photosynthesis is not sufficient to sustain metabolism and for supporting new shoot growth in the spring (Stier and Fei, 2008). In addition, it has been well demonstrated that the accumulation of carbohydrates during cold acclimation enhances freezing tolerance (Stitt and Vaughan, 2002). In grasses originated in the subtropical region, such as bermudagrass, the overwintering reserves are mainly represented by glucose polymers (starch) and sucrose (White, 1973). Numerous studies demonstrated a decrease of starch concentration and an accumulation of WSC and proline in rhizomes and stolons of warm-season turfgrasses during cold acclimation (Kavi Kishor et al., 2005; Patton et al., 2007; Verbruggen and Hermans, 2008; Zhang et al., 2006). Moreover, recent researches conducted in northeastern Italy reported a strong positive correlation between concentration of WSC in stolons and spring green-up of bermudagrass cultivars (Macolino et al., 2010; Rimi et al., 2013b).

Several studies investigating stress physiology pointed out that various proteins and nitrogen compounds, together with the carbohydrates content, contribute to stress tolerances, including resistance to freezing (Gatschet et al., 1994; Stier and Fei, 2008). 
Gatschet et al. (1994) observed an enhanced synthesis of proteins with low-intermediate molecular weight having an unknown function in cold-tolerant bermudagrass during winter acclimation. On the basis of this knowledge, late-season nitrogen $(\mathrm{N})$ fertilization has been shown to enhance spring green-up of bermudagrass by various researchers (Goatley et al., 1998; Munshaw et al., 2006; Richardson, 2002). In fact, it has been shown that fall $\mathrm{N}$ applications on bermudagrass promote fall color retention and spring green-up, which has been likely related to an increased accumulation of proteins (Munshaw et al., 2006; Richardson, 2002; Rimi et al., 2013b). However, researches that tested management practices on several bermudagrasses suggested that cultivar selection is more important than cultural practices in determining the success of bermudagrass in the transition zone (Munshaw et al., 2006; Rimi et al., 2011, 2013b).

To improve genetic selection processes and cultivar selection of bermudagrass for transitional environments, it seems crucial to investigate on the relationship between spring green-up and selected components of stolon reserves. Therefore, the objectives of this study were to evaluate contents of nonstructural carbohydrates and $\mathrm{CP}$ in stolons of seeded bermudagrass cultivars during late winter in a transition zone and to assess the relationships between these reserves and spring green-up.

\section{Materials and Methods}

A 2-year (2009-10) field experiment was carried out at the agricultural experimental farm of Padova University in Legnaro (lat. $45^{\circ} 20^{\prime \prime} \mathrm{N}$, long. $11^{\circ} 57^{\prime \prime} \mathrm{E}$, elevation $8 \mathrm{~m}$ ), northeastern Italy. The area has a humid subtropical climate (similar to U.S. Department of Agriculture plant hardiness zone 8 ) with an annual mean temperature of $13.5^{\circ} \mathrm{C}$ and precipitation of $826 \mathrm{~mm}$ (Table 1). The soil at the site was an Oxyaquic Eutrudept, coarsesilty, mixed, mesic $(25.6 \%$ sand, $62.2 \%$ silt, and $12.2 \%$ clay) with $\mathrm{pH}$ of $8.2,1.5 \%$ organic matter, $\mathrm{N}$ content of $8.6 \mathrm{mg} \cdot \mathrm{kg}^{-1}, 23.5 \mathrm{mg} \cdot \mathrm{kg}^{-1}$ of available phosphorus (P), and $119 \mathrm{mg} \cdot \mathrm{kg}^{-1}$ exchangeable potassium (K).

The bermudagrass cultivars used for the study were 'Caribe', 'Princess-77', 'Mohawk', 'Sultan', 'SWI 1012', and 'Jackpot'. The plots $(1.5 \times 2.0 \mathrm{~m})$ were seeded on 25 May 2009 at a rate of $7 \mathrm{~g} \cdot \mathrm{m}^{-2}$ pure live seed and were arranged in a randomized complete block design with four replicates. A slow-release fertilizer $(20 \mathrm{~N}-2.2 \mathrm{P}-6.6 \mathrm{~K})$ was applied in May, June, and August at a rate of $50 \mathrm{~kg} \mathrm{~N} / \mathrm{ha}$ for a total of $150 \mathrm{~kg} \mathrm{~N} / \mathrm{ha} /$ year. Irrigation was provided using a sprinkler system and was limited to the first month of the establishment period (May to June 2009). During the growing period (April to September), plots were mowed weekly with a rotary mower at an effective cutting height of $36 \mathrm{~mm}$ with clippings removed. In December of each year, broadleaf weeds were controlled with an application of selective herbicide dicamba (3,6-dichloro-2methoxybenzoic acid) at $0.1 \mathrm{~kg} \cdot \mathrm{ha}^{-1}$.

On 11 Mar. 2010 and 2 Mar. 2011, a turf sample measuring $20 \times 20 \times 4$ (depth) $\mathrm{cm}$ was collected from each plot for morphological measurements and laboratory analyses. Early March was chosen as the sampling period on the basis of historical records of bermudagrass spring green-up, because it commonly represents the last weeks of full dormancy in the area of investigation. The samples were washed with running water to separate soil from the vegetative part; and subsequently the stolons were manually separated from rhizomes (Richardson, 2002), leaves, and roots. From each sample, seven stolon fragments of three internodes, totaling 21 internodes, were randomly selected to measure the stolon diameter. A digital caliber was used to measure the diameter of internodes, defined as midpoint between two consecutive nodes, and the data were averaged to obtain one value. Successively, the stolons and rhizomes were freeze-dried and weighed using an analytical balance to determine the dry weight per area unit $\left(\mathrm{g} \cdot \mathrm{m}^{-2}\right)$. The WSC were extracted from dried and grounded stolon tissue using an $80 \%$ ethanol solution following a hot water extraction protocol (Suzuki, 1968). Successively, WSC were quantified by colorimeter after reaction with

Table 1. Monthly mean air temperatures and monthly precipitations from 2009 to 2011 and long-term averages (1963-2009) at the agricultural experimental farm of Padova University, Legnaro, northeastern Italy.

\begin{tabular}{|c|c|c|c|c|c|c|c|c|}
\hline \multirow[b]{2}{*}{ Month } & \multicolumn{4}{|c|}{ Air temp $\left({ }^{\circ} \mathrm{C}\right)$} & \multicolumn{4}{|c|}{ Precipitation (mm) } \\
\hline & 2009 & 2010 & 2011 & $47-y r$ avg & 2009 & 2010 & 2011 & $47-y r$ avg \\
\hline$\overline{\text { January }}$ & 2.9 & 2.5 & 7.3 & 3.5 & 57 & 59 & 11 & 52 \\
\hline February & 5.2 & 4.9 & 9.4 & 4.8 & 57 & 127 & 45 & 48 \\
\hline March & 9.0 & 8.1 & 12.9 & 8.7 & 104 & 38 & 98 & 57 \\
\hline April & 14.3 & 13.7 & 14.9 & 12.6 & 126 & 45 & 48 & 70 \\
\hline May & 20.2 & 17.7 & 18.6 & 18.1 & 26 & 110 & 40 & 73 \\
\hline June & 21.6 & 21.9 & 19.9 & 21.3 & 87 & 111 & 63 & 86 \\
\hline July & 24.2 & 24.7 & 19.4 & 23.2 & 79 & 96 & 138 & 73 \\
\hline August & 25.3 & 22.4 & 21.5 & 23.3 & 21 & 91 & 27 & 75 \\
\hline September & 20.8 & 17.9 & 18.9 & 18.8 & 190 & 112 & 13 & 73 \\
\hline October & 14.3 & 12.7 & 12.8 & 14.2 & 44 & 87 & 90 & 78 \\
\hline November & 10.7 & 9.8 & 8.9 & 8.7 & 92 & 153 & 80 & 78 \\
\hline December & 3.8 & 2.6 & 4.6 & 4.4 & 113 & 112 & 23 & 63 \\
\hline Annual & 14.4 & 13.3 & 14.1 & 13.5 & 996 & 1141 & 601 & 826 \\
\hline
\end{tabular}

anthrone (9,10-dihydro-9-oxoanthracene) using glucose as a standard (Van Handel, 1968). For starch analysis, an additional $100 \mathrm{mg}$ of stolon ground tissue was used after being washed twice with $80 \%$ ethanol at a temperature of $80{ }^{\circ} \mathrm{C}$. The ethanol-extracted residue was starch digested by adding $3.0 \mathrm{~mL}$ thermo stable $\alpha$-amylase (A3306 from Bacillus licheniformis; Sigma-Aldrich, St. Louis, MO) and $0.1 \mathrm{~mL}$ amyloglucosidase solution (A7255 from Rhizopus mold; Sigma-Aldrich). Tubes were centrifuged and glucose in the supernatant was determined using high-performance liquid chromatography. Starch concentration was estimated as $0.9 \times$ glucose concentration (McCleary et al., 1997). Total $\mathrm{N}$ was extracted from $700 \mathrm{mg}$ of stolon ground tissue using the Kjeldahl method and CP was determined as $\mathrm{N} \times 6.25$ (Jones, 1991).

The percentage of green cover of each plot was visually rated every $10 \mathrm{~d}$ from April to June of 2010 and 2011. Subsequently, a sigmoidal model (Graphpad Prism 5.0 for Windows; Graphpad Software, La Jolla, CA) was used to calculate days of year, beginning on 1 Jan., needed to reach $80 \%$ green cover (D80). Coefficients of determination for the model were the following: 'Caribe', $2010=$ 0.99 and $2011=0.97$; 'Mohawk', $2010=$ 0.99 and $2011=0.98$; 'Princess-77', 2010 $=1$ and $2011=1$; 'Sultan', $2010=0.99$ and $2011=0.98$; 'SWI 1012', $2010=0.99$ and $2011=0.98$; and 'Jackpot', $2010=0.99$ and $2011=0.98$. Stolons and rhizomes dry weight, stolon diameter, WSC, starch and $\mathrm{CP}$ content, and D80 were subjected to the analysis of variance (ANOVA) using SAS Proc Mixed (Version 9.2; SAS Institute, Cary, NC). Where appropriate, Fisher's protected least significant difference test was used at the $0.05 P$ level to identify significant differences between means. SAS Proc Corr (Version 9.2; SAS Institute) was used to investigate the relationship among stolon dry weight, stolon diameter, content of WSC, starch and CP, and D80.

\section{Results and Discussion}

Spring green-up. The sigmoidal trend was appropriate for describing the green-up of all cultivars in Spring 2010 and 2011 (Fig. 1). In both years, 'Princess-77' showed a slower green-up compared with the other five cultivars, which had similar trends. The ANOVA for D80 revealed a two-way interaction cultivar $\times$ year $(P<0.001)$ and significant main effect of cultivar $(P<0.001)$. In 2010 , significant differences occurred only between 'Princess-77' and 'SWI 1012', whereas in 2011, 'Sultan' showed the earliest green-up followed by 'SWI 1012', 'Jackpot', 'Mohawk', and last by 'Princess-77' (Table 2). In 2011, 'Princess-77' reached $80 \%$ green cover significantly later compared with the previous year with a delay of $9 \mathrm{~d}$ compared with the average of the other five cultivars (Table 2). Because the Winter 2010-11 was less severe than 2009-10 (Table 1), the higher magnitude of difference among cultivars observed in 2011 than 2010 could be attributed to high 
precipitation that occurred in early May 2010 (Table 1). Moreover, the slow green-up of 'Princess-77' observed in this study is in agreement with previous research conducted in the same area (Macolino et al., 2010; Rimi et al., 2013a).

Morphological parameters. The ANOVA for stolon dry weight revealed significant main effects of cultivar $(P<0.05)$, year $(P<0.01)$, and their interaction $(P<0.001)$. In 2010, 'Princess-77' had higher stolon dry weight than 'Sultan', 'Mohawk', and 'Caribe', whereas in 2011, 'Jackpot' and 'Mohawk' showed lower values compared with other cultivars, which did not differ between each other (Table 2). These results suggest a large role of environmental pressure in determining differences in stolon mass for the cultivars studied. With the exception of 'Jackpot', significant increments of stolon dry weight were noted for all the cultivars between Mar. 2010 and Mar. 2011 (Table 2). The largest increases in stolon dry weight were observed for 'Caribe' $\left(+302 \mathrm{~g} \cdot \mathrm{m}^{-2}\right)$ and 'Sultan' $\left(+232 \mathrm{~g} \cdot \mathrm{m}^{-2}\right)$. The differences between stolon dry weight of Mar. 2010 and 2011 denoted an increment of stolon mass with advancing maturity of turfgrass, which agreed with numerous previous findings (Beard, 1973; Christians, 1998; Rimi et al., 2013b).

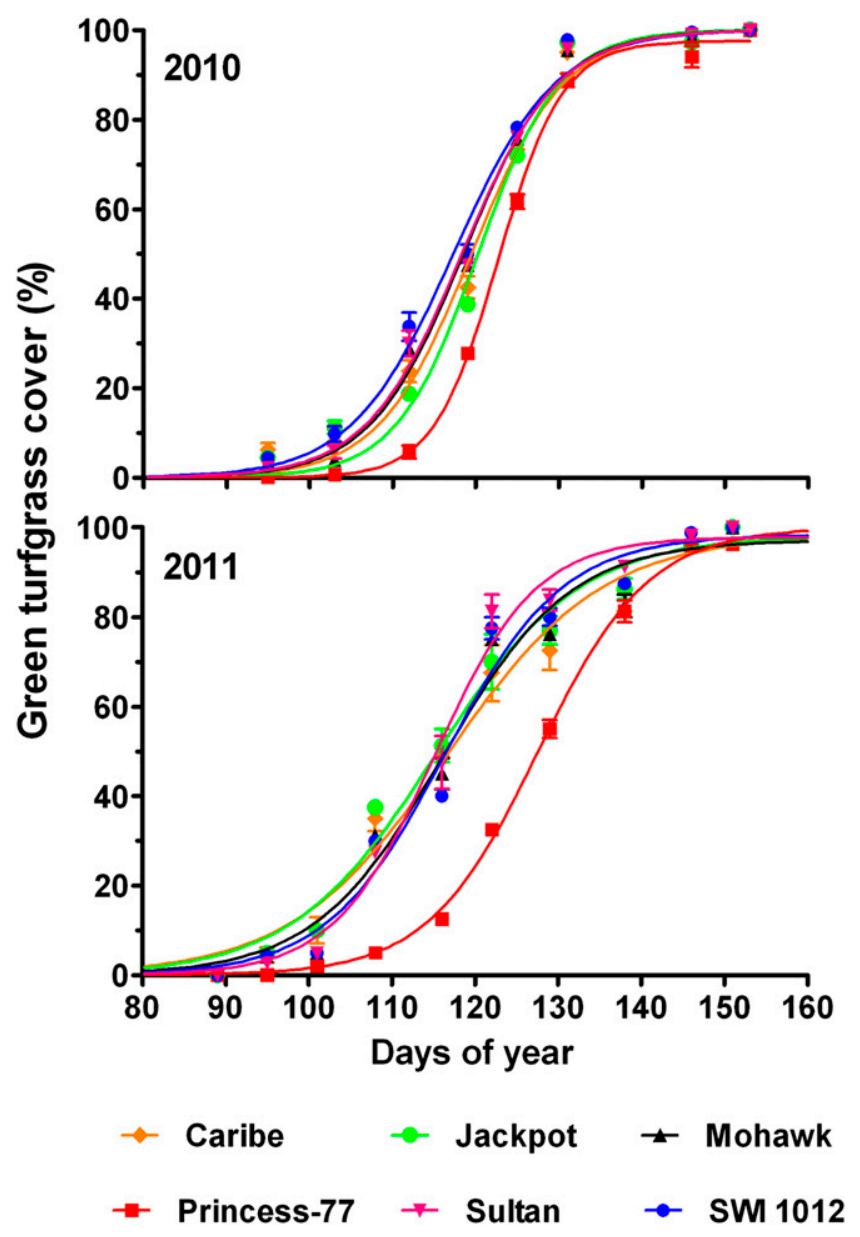

Fig. 1. Percent green cover as a function of number of days of the year for six bermudagrass cultivars in 2010 and 2011. Data points represent an average of four replicates and vertical bars indicate $\pm \mathrm{SE}$.

Similar to stolon dry weight, the stolon diameter was affected by the effects of cultivar $(P<0.001)$, year $(P<0.01)$, and their interaction $(P<0.05)$. In 2010, there were differences only between 'Princess-77' and 'SWI 1012', whereas in 2011, 'Princess-77' had the smallest stolon diameter compared with the other cultivars, among which there were no differences (Table 2). An increase in stolon diameter was observed between 2010 and 2011 for 'Caribe', 'Mohawk', 'Sultan', and 'Jackpot', whereas 'Princess-77' and 'SWI 1012' showed no variations (Table 2). When these results are compared with the cultivar responses for stolon dry weight (Table 2), it appears that diameter is not likely to be mainly responsible for stolon mass, but other traits (e.g., internodes length and/or dry weight of single internodes) should be considered.

Rhizome production was observed only in 2011, with no significant differences in dry weight occurred among cultivars (data not shown). In 2011, the overall rhizomes dry weight was greater than $10 \mathrm{~g} \cdot \mathrm{m}^{-2}$, which agreed with previous studies reporting that stolons are the major storage organs of bermudagrass, especially during the seeding year (Munshaw et al., 2001; Richardson et al., 2004, 2005). Moreover, when the stolons and rhizomes dry weight 2011 data were compared, the rhizomes represented only a small fraction of the overwintering structures. This suggests that rhizomes may be important for plant survival after dramatic winterkill but of minimal importance for full recovery of a functional turf. Further research is needed to learn more about stolons and rhizome development and how the stolons-to-rhizomes ratio changes over time in bermudagrass turf.

Carbohydrates and crude protein. The ANOVA revealed differences among cultivars for starch content $(P<0.001)$, whereas year and cultivar $\times$ year interaction were not significant $(P \geq 0.05)$; consequently, the data were pooled over the 2 years. The cultivar SWI 1012 had higher starch content in stolons compared with the others followed by 'Sultan', whereas 'Princess-77' had the lowest content (Fig. 2). The starch content of 'Princess-77' was $\approx 35 \%$ lower than 'SWI 1012 ' and $\approx 25 \%$ lower than the average of the remaining cultivars (Fig. 2). These results are in agreement with previous research, which demonstrated that 'Princess-77' had significant lower carbohydrate reserves than

Table 2. Days of year to reach $80 \%$ green cover (assessed visually and based on sigmoidal model estimates), stolon dry weight, diameter, and crude protein content of six bermudagrass cultivars in 2010 and 2011 at Legnaro, northeastern Italy.

\begin{tabular}{|c|c|c|c|c|c|c|c|c|}
\hline Cultivar & \multicolumn{2}{|c|}{ Days of yr to reach $80 \%$ green cover (d) } & \multicolumn{2}{|c|}{ Stolons dry wt $\left(\mathrm{g} \cdot \mathrm{m}^{-2}\right)$} & \multicolumn{2}{|c|}{ Stolon diam (mm) } & \multicolumn{2}{|c|}{ Crude protein in stolons $\left(\mathrm{g} \cdot \mathrm{kg}^{-1}\right.$ dry wt) } \\
\hline Jackpot & $128 \mathrm{abA}$ & $128 \mathrm{bcA}$ & $321 \mathrm{abcA}$ & $385 \mathrm{bA}$ & $1.03 \mathrm{abB}$ & $1.22 \mathrm{aA}$ & $103 \mathrm{bA}$ & $60 \mathrm{abB}$ \\
\hline Mohawk & $127 \mathrm{abA}$ & $128 \mathrm{bcA}$ & $292 \mathrm{bcB}$ & $377 \mathrm{bA}$ & $0.99 \mathrm{abB}$ & $1.18 \mathrm{aA}$ & $97 \mathrm{bcA}$ & $55 \mathrm{bB}$ \\
\hline Sultan & $127 \mathrm{abA}$ & $125 \mathrm{dA}$ & $253 \mathrm{cdB}$ & $485 \mathrm{aA}$ & $0.98 \mathrm{abB}$ & $1.32 \mathrm{aA}$ & $89 \mathrm{cdA}$ & $60 \mathrm{abB}$ \\
\hline SWI 1012 & $126 \mathrm{bA}$ & $127 \mathrm{cA}$ & $350 \mathrm{abB}$ & $451 \mathrm{abA}$ & $1.06 \mathrm{aA}$ & $1.21 \mathrm{aA}$ & $86 \mathrm{dA}$ & $61 \mathrm{abB}$ \\
\hline
\end{tabular}

${ }^{\mathrm{z}}$ Values with the same lowercase letter in the same column are not significantly different from one another at $P=0.05$ between cultivars. Values with the same uppercase letter in the same row and measurement parameter are not significantly different from one another at $P=0.05$ between years. 
more cold-tolerant cultivars such as 'Riviera' (Zhang et al., 2006) and 'Yukon' (Rimi et al., 2013b). According to this, varietal selection appears to play a dominant role in the starch content of overwintering stolons. The stolon contents of WSC were unaffected by cultivar or year of investigation $(P \geq 0.05)$ and were equal to $80 \mathrm{~g} \cdot \mathrm{kg}^{-1}$ dry weight on average (data not shown). These values are less than half compared with the starch concentrations in stolons (Fig. 2), which corroborates that starch represents the main nonstructural carbohydrate reserves in bermudagrass (Stier and Fei, 2008).

The ANOVA revealed that stolon content of $\mathrm{CP}$ was influenced by cultivar, year $(P<$ $0.001)$, and their interaction $(P<0.01)$. All the cultivars tested displayed lower concentration of CP in 2011 than 2010, although the highest difference occurred for 'Princess-77' (-50 g. $\mathrm{kg}^{-1}$ dry weight; Table 2$)$. The varying content of $\mathrm{CP}$ between years may be the result of contrasting hardening conditions (Table 1) and could also be explained by higher stolon dry weight and consequent intraspecies competition in 2011 (de Kroon

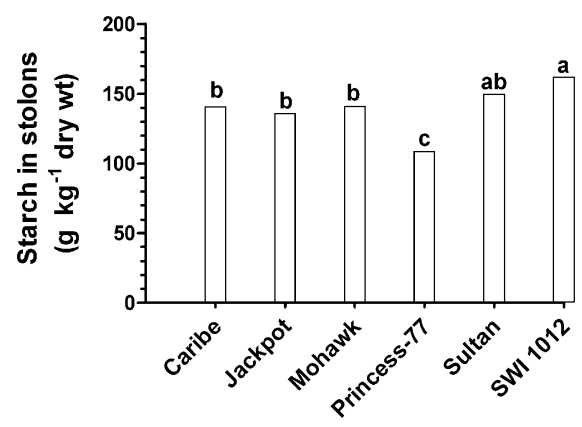

Fig. 2. Content of starch in stolons of six bermudagrass cultivars in March. Data are pooled over 2 years (2010 and 2011) and four replications $(\mathrm{n}=8)$. Different letters on top of each bar denote statistical differences according to Fisher's protected least significant difference test at $P=0.05$.

Table 3. Correlations among days to reach $80 \%$ green cover (D80), stolon concentrations of starch, watersoluble carbohydrates (WSC), and crude protein (CP), stolons dry weight, and diameter for six bermudagrass cultivars in 2010 and 2011. ${ }^{\mathrm{z}}$

\begin{tabular}{|c|c|c|c|c|c|}
\hline Parameter & Starch & WSC & $\mathrm{CP}$ & Stolons dry wt & Diam \\
\hline & & & 2010 & & \\
\hline D80 & $-0.69 * * *$ & $-0.14 \mathrm{NS}$ & $0.70 * * *$ & $0.21 \mathrm{Ns}$ & $-0.31 \mathrm{NS}$ \\
\hline Starch & - & $0.39 \mathrm{NS}$ & $-0.77 * * *$ & $-0.17 \mathrm{NS}$ & $0.36 *$ \\
\hline WSC & - & - & $-0.19 \mathrm{NS}$ & $-0.02 \mathrm{NS}$ & $0.33 \mathrm{NS}$ \\
\hline $\mathrm{CP}$ & - & - & - & $0.33 \mathrm{NS}$ & $-0.31 \mathrm{NS}$ \\
\hline \multirow[t]{2}{*}{ Stolons dry wt } & - & - & - & - & $-0.01 \mathrm{NS}$ \\
\hline & & & 2011 & & \\
\hline D80 & $-0.48 *$ & $0.17 \mathrm{NS}$ & $0.29 \mathrm{NS}$ & $0.23 \mathrm{NS}$ & $-0.69 * *$ \\
\hline Starch & - & $-0.10 \mathrm{NS}$ & $-0.55 * *$ & $0.23 \mathrm{NS}$ & $0.49 *$ \\
\hline WSC & - & - & $0.12 \mathrm{NS}$ & $0.09 \mathrm{NS}$ & $-0.18 \mathrm{NS}$ \\
\hline $\mathrm{CP}$ & - & - & - & $0.16 \mathrm{NS}$ & $-0.37 \mathrm{NS}$ \\
\hline Stolons dry wt & - & - & - & - & $-0.12 \mathrm{NS}$ \\
\hline
\end{tabular}

et al., 1994; Rimi et al., 2013b). Differences among cultivars in stolon CP were not consistent between the 2 years of investigation with larger differences observed in 2010 than 2011. In 2010, 'Princess-77' had the higher concentration of $\mathrm{CP}$ than other cultivars, est CP content, whereas in 2011, 'Princess-77' differed only from 'Mohawk' (Table 2). These findings are similar to those of Rimi et al. (2013a), who reported that 'Princess-77' had higher content of $\mathrm{CP}$ in stolons along with lower content of nonstructural carbohydrates in comparison with several bermudagrass cultivars.

Correlations. Correlation analyses revealed a negative correlation between D80 and starch content in both 2010 and 2011, whereas no correlations were observed between WSC and D80 (Table 3). These findings indicate that cultivars with high concentration of starch in the winter greenup earlier in the spring than those with low concentrations, whereas such effect is not attributable to WSC. This appears in partial contradiction with previous studies that reported a strong relationship between stolon content of WSC and green-up of bermudagrass cultivars (Macolino et al., 2010; Rimi et al., 2013b). The different outcomes observed in these studies may be the result of the contrasting cultivars tested, again suggesting a high influence of genotype in predicting spring green-up

Interestingly, negative correlations were detected between CP and starch in both years of study, and there was also a positive correlation between CP and D80 in 2010 (Table 3). These results suggest that high starch-accumulating cultivars would be preferred over those with high $\mathrm{CP}$ content in stolons to achieve rapid spring green-up. In addition, correlation analyses revealed no significant relationships between D80 and stolon dry weight, whereas there was a negative correlation between D80 and diameter in 2011 (Table 3). Finally, stolon diameter was positively correlated with starch content in both 2010 and 2011, whereas 'Sultan' and 'SWI 1012' had the low- suggesting that stolon coarseness could be used as a phenological indicator to help breeders improve bermudagrass green-up. However, further research appears necessary to learn more about the relationships occurring among the traits studied and to validate a prediction model for spring green-up.

\section{Conclusions}

Based on the results of this study, 'Princess77' displayed poor adaptation to the environmental conditions of northeastern Italy among the cultivars studied, showing low levels of starch in the stolons and slow greenup. The starch content in stolons of bermudagrasses in late winter was positively correlated with the speed of spring greenup. Moreover, this study revealed minimal impact of stolon WSC content on spring green-up of bermudagrasses, whereas starch appeared the most important overwintering reserve for spring recovery. Stolon diameter was positively correlated with starch content, suggesting that stolon diameter could be used as a predictor for early spring green-up in bermudagrasses. The ability to accumulate and maintain large reserves of starch could also be used in selecting bermudagrass cultivars with early green-up for transition zone environments.

\section{Literature Cited}

Anderson, J.A. and C.M. Taliaferro. 2002. Freeze tolerance of seed-producing turf bermudagrasses. Crop Sci. 42:190-192.

Anderson, J.A., C.M. Taliaferro, and D.L. Martin. 2003. Longer exposure durations increase freeze damage to turf bermudagrasses. Crop Sci. 43: 973-977.

Anderson, J.A., C.M. Taliaferro, and Y.Q. Wu. 2007. Freeze tolerance of seed- and vegetativelypropagated bermudagrasses compared with standard cultivars. Online. Applied Turfgrass Science. doi: 10.1094/ATS-2007-0508-01-RS.

Beard, J.B. 1973. Turfgrass: Science and culture. Prentice-Hall, NJ.

Blum, A. 1988. Plant breeding for stress environments. CRC Press, Boca Raton, FL. p. 114-132

Burton, G.W., J.E. Hook, J.L. Butler, and R.E. Hellwig. 1988. Effect of temperature, daylength, and solar radiation on production of coastal bermudagrass. Agron. J. 80:557-560.

Christians, N.C. 1998. Fundamentals of turfgrass management. Ann Arbor Press, Chelsea, MI.

Croce, P., A. De Luca, M. Mocioni, M. Volterrani, and J.B. Beard. 2004. Adaptability of warm season turfgrass species and cultivars in a Mediterranean climate. Acta Hort. 661:365-368.

de Kroon, H., J.F. Stuefer, M. Dong, and H.J. During. 1994. On plastic and non-plastic variation in clonal plant morphology and its ecological significance. Folia Geobot. Phytotaxon. 29:123-138.

Duble, R.L. 1996. Turfgrasses, their management and use in the southern zone. 2nd Ed. Texas A\&M University Press, College Station, TX. p. 1-323.

Fiorio, S., S. Macolino, and B. Leinauer. 2012. Establishment and performance of bluegrass species and tall fescue under reduced-input maintenance in a temperate Mediterranean environment. HortTechnology 22:810-816. 
Gatschet, M.J., C.M. Taliaferro, J.A. Anderson, D.R. Porter, and M.P. Anderson. 1994. Cold acclimation and alterations in protein synthesis in bermudagrass crowns. J. Amer. Soc. Hort. Sci. 119:477-480.

Goatley, J.M., V.L. Maddox, and K.L. Hensler. 1998. Late-season applications of various nitrogen sources affect colour and carbohydrate content of 'Tiflawn' and Arizona common bermudagrass. HortScience 33:692-695.

Graber, L.F., N.T. Nelson, W.A. Luekel, and W.B. Albert. 1927. Organic food reserves in relation to the growth of alfalfa and other perennial herbaceous plants. Wisconsin Agr. Exp. Sta. Res. Bull. 80.

Hannah, M.A., D. Wiese, S. Freund, O. Fiehn, A.G. Heyer, and D.K. Hincha. 2006. Natural genetic variation of freezing tolerance in Arabidopsis. Plant Physiol. 142:98-112.

Harlvonson, W.L. and P. Guertin. 2003. Cynodon dactylon (L.) Pers. USGS weeds in the Westproject: Status of introduced plants in southern Arizona parks, p. 44. U.S. Geological Survey/ Southwest Biological Science Center, Sonoran Desert Field Station, University of Arizona, Tucson, AZ.

Jones, J.B. 1991. Kjeldahl method for nitrogen determination. Micro-Macro Publishing, Athens, GA.

Kavi Kishor, P.B., S. Sangam, R.N. Amrutha, P. Sri Laxmi, K.R. Naidu, K.R.S.S. Rao, S. Rao, K.J. Reddy, P. Theriappan, and N. Sreenivasulu. 2005. Regulation of proline biosynthesis, degradation, uptake and transport in higher plants: Its implications in plant growth and abiotic stress tolerance. Curr. Sci. 88:424 438.

Macolino, S., M. Serena, B. Leinauer, and U. Ziliotto. 2010. Preliminary finding on the correlation between water-soluble carbohydrate content in stolons and first year green-up of seeded bermudagrass cultivars. HortTechnology 20: 758-763.

McCleary, B.V., T.S. Gibson, and D.C. Mugford. 1997. Measurement of total starch in cereal products by amyloglucosidase- $\alpha$-amylase method: Collaborative study. J. AOAC Intl. 80: 571-579.

Munshaw, G.C., E.H. Ervin, C. Shang, S.D. Askew, X. Zhang, and R.W. Lemus. 2006. Influence of late-season iron, nitrogen, and seaweed extract on fall color retention and cold tolerance of four bermudagrass cultivars. Crop Sci. 46:273-283.

Munshaw, G.C., D.W. Williams, and P.L. Cornelius. 2001. Management strategies during the establishment year enhance production and fitness of seeded bermudagrass stolons. Crop Sci. 41: 1558-1564.

Patton, A.J., S. Cunningham, J.J. Volenec, and Z. Reicher. 2007. Difference in freeze tolerance of zoysiagrasses: II. Carbohydrate and proline accumulation. Crop Sci. 47:2170-2181.

Patton, A.J., M.D. Richardson, D.E. Karcher, J.W. Boyd, Z.J. Reicher, J.D. Fry, J.S. McElroy, and G.C. Munshaw. 2008. A guide to establishing seeded bermudagrass in the transition zone. Online. Applied Turfgrass Science. doi: 10.1094/ ATS-2008-0122-01-MD.

Richardson, M.D. 2002. Turf quality and freezing tolerance of 'Tifway' bermudagrass as affected by late-season nitrogen and trinexapac-ethyl. Crop Sci. 42:1621-1626.

Richardson, M.D., D.E. Karcher, P. Berger, and J.W. Boyd. 2004. Utilizing improved seeded bermudagrasses on transition-zone sport fields. Acta Hort. 661:369-374.

Richardson, M.D, D.E. Karcher, and J.W. Boyd. 2005. Winter survival of seeded bermudagrass: The recent development of high-quality seeded bermudagrasses makes the choice of this species for fairways even more appealing. U.S. Golf Assn. Green Section Record 43:15-18.

Rimi, F., S. Macolino, B. Leinauer, and U. Ziliotto. 2011. Green-up of seeded bermudagrass cultivars as influenced by spring scalping. HortTechnology 21:230-235.

Rimi, F., S. Macolino, M.D. Richardson, D.E. Karcher, and B. Leinauer. 2013a. Influence of three nitrogen fertilization schedules on bermudagrass and seashore paspalum: I. Spring green-up and fall color retention. Crop Sci. 53:1161-1167.

Rimi, F., S. Macolino, M.D. Richardson, D.E. Karcher, and B. Leinauer. 2013b. Influence of three nitrogen fertilization schedules on bermudagrass and seashore paspalum: II. Carbohydrates and crude protein in stolons. Crop Sci. 53:1168-1178.

Sinclair, T.R., P. Misley, D. Jeffrey, and D. Ray. 2001. Short photoperiod inhibits winter growth of subtropical grasses. Planta 213:488-491.

Stier, J.C. and S.Z. Fei. 2008. Cold stress physiology and management of turf-grasses, p. 473505. In: Pessarakli, M. (ed.). Handbook of turfgrass management and physiology. CRC Press, Boca Raton, FL.

Stitt, M. and H. Vaughan. 2002. A plant for all seasons: Alterations in photosynthetic carbon metabolism during cold acclimation in Arabidopsis. Curr. Opin. Plant Biol. 5:199-206.

Suzuki, M. 1968. Fructosan in the timothy haplocorm. Can. J. Bot. 46:1201-1206.

Trenholm, L.E., A.E. Dudeck, J.B. Sartain, and J.L. Cisar. 1998. Bermudagrass growth, total non structural carbohydrate concentration and quality as influenced by nitrogen and potassium. Crop Sci. 38:168-174.

Van Handel, E. 1968. Direct microdetermination of sucrose. Anal. Biochem. 22:13411346.

Verbruggen, N. and C. Hermans. 2008. Proline accumulation in plants: A review. Amino Acids 35: 753-779.

White, L.M. 1973. Carbohydrate reserves of grasses: A review. J. Range Mgt. 26:13-18.

Zhang, X., E.H. Ervin, and A.J. La Branche. 2006. Metabolic defense responses of seeded bermudagrass during acclimation to freezing stress. Crop Sci. 46:2598-2605.

Zhen, Y. and M.C. Ungerer. 2008. Clinal variation in freezing tolerance among natural accessions of Arabidopsis thaliana. New Phytol. 177:419-427. 